\title{
"Nice Shoes."
}

\section{Lisa O'Connor, Guest Columnist}

Correspondence for Reference \& User Services Quarterly should be addressed to Editor Diane Zabel, Schreyer Business Library, The Pennsylvania State University, 309 Paterno Library, University Park, PA 16802; e-mail:dxz2@ psu.edu.

Lisa O'Connor is Assistant Professor, School of Library \& Information Science, University of Kentucky, Lexington.
What could be more appropriate for the fall issue than an editorial on library education? I was delighted when Lisa O'Connor accepted my invitation to contribute a guest editorial on this topic. Lisa O'Connor earned her MLIS from the University of South Carolina in 1995. She served as a reference and business librarian at Youngstown State University and as business librarian and instructional services coordinator at Kent State University. She earned her Ph.D. in Cultural Foundations of Education from Kent State in 2006. She has been teaching at the University of Kentucky for three years. Her teaching areas are foundations of librarianship, information sources and services, instructional services, and business sources and services. Her research interests include information literacy, information seeking in business, and business librarianship.-Editor

I have wanted to teach in a library school from the time I completed my MLIS. After a very satisfying decade working as a librarian, there I was ... I had completed my first semester teaching what could only be called a brilliant (well, by me, anyway) course on instructional services and was ready to read the rave reviews in my student course evaluations. Understand . . I had put my heart and soul into this course. I slid them out of their envelope with anticipation, and there, on the first form in the comments section, it caught my eye immediately . . . "Nice shoes."

Nice shoes?! That's it? My creative pedagogy? My professional insight? All those witty and wildly entertaining anecdotes ... And that's the assessment? ... My feet are well-shod? Of course, that was not the last time in my young career student comments on course evaluations have shocked, amazed, and amused me, but I'll come back to them later.

Since joining the School of Library and Information Science at the University of Kentucky, I have become painfully aware of the flurry of attention library education is garnering lately. There is a crisis, I understand. Or there is no crisis, depending upon whom you ask. I-school? L-school? Some believe LIS programs are forsaking librarianship. Others believe LIS programs face extinction if they do not embrace the future ... the debate rages, and both sides have compelling cases.

I have read articles, listened to presentations, and attended forums. I have thought through these issues and come to very little in the way of conclusions. In some way, the tribulations seem age-old. Technology has been challenging and transforming our discipline since electricity enabled libraries to open in the evening. As libraries emerged from 
dusty, scholarly repositories into lively institutions serving the common working man, the necessity for reference assistance emerged as well. Microfilm, librarians feared, would displace them. In reality it created so much new work that the profession could barely educate an adequate workforce fast enough. Now, more modern information technology seems the most serious threat yet.

I recognize something else in this "crisis" as well, something that is neither unique to this age nor to this discipline: it is the tension that has existed between education and practice since professional education moved to the university. This conflict is unique to applied disciplines, and it resonates with me on a very personal level. Having spent the past three years making the transition from practitioner to educator myself, I recognize this tension not only in the Question (with a capital Q) of library education, but also in the questions emanating from the everyday business of educating new library and information professionals. The issues in the national debate are often perfectly mirrored in my own professional life. Like the Question of library education, the everyday problems resulting from conflict between the demands of practice and educational aims seem intractable to me. So I offer little other than observations here in the hopes that there is utility in describing them, even though they are neither new nor necessarily solvable.

\section{“THERE'S NO TEACHING GOING ON HERE, JUST A BUNCH OF READING."}

I understand that online education is good for this profession. We need to train enough librarians to replace baby boomer retirees. More importantly, we need a diverse work force, and computer-based education will ultimately allow us to recruit people into the field who were previously barred by geographical and temporal constraints. I know enormous areas of the country are short on LIS professionals because they are not served by local schools. I know there are shortages in entire subfields, such as the school media specialty. I know we need online education, and, more to the point, I know it's here to stay.

With all that going for it, admitting (particularly in print) you're not a believer is difficult these days. As a teacher, however, I see firsthand that it has some very negative educational outcomes.

The first time I taught an online course I was excited by the challenge-I still am in some respects. My institution has a fairly sizable distance cohort, but in comparison to some other programs, it is quite humanely organized. Class sizes are capped at twenty-five, just as with face-to-face courses. Most of our students are in metropolitan areas that are fewer than two hours away, so we are able to require some faceto-face meetings in addition to our Blackboard component. Typically our courses meet two to three times during the semester for a couple of hours. We also have some terrific technologies, such as Captivate and Camtasia, that allow us to include instruction with audio-visual components.
I've learned to mediate really good class discussions. When substantive questions are asked, substantive participation is usually generated without arbitrary quantitative requirements for postings by students.

All this is to say that I consider our distance courses quite good-perhaps as good as they come for asynchronous education (we do teach synchronous classes at remote locations, as well, but those are not my topic here). Despite all of its appeal, however, many of my students are not adequately prepared or motivated to take courses online. Course evaluations for online versions of the face-to-face courses we teach are nearly always lower than the face-to-face versions, and not just for me, but for many of my colleagues at the university as well. Comments such as "There's no teaching here ... just a lot of reading" and "This course would be better face-to-face" abound. Asynchronous distance courses require a phenomenal amount of self-discipline, a tremendously independent attitude toward learning, and, yes, much more reading than traditional classrooms. Only a few rare students each semester flourish in this environment, and, I will say, they are a true delight. Yet, though students clamor for more and more online offerings, course evaluations and anecdotal evidence suggest that most of them are dissatisfied with the overall experience. As one of my colleagues is fond of saying, it's like the man who complained after eating in a restaurant, "The food was terrible and the portions were way too small."

\section{"CAPTIVATE BITES MY A**"}

What distinguishes professional education from other, more academic disciplines is, of course, the element of immediate application through practice. On one hand, it is the most satisfying part of my work; knowing that my students are going out into the real world to serve society and promote the democratic distribution of information is truly thrilling. When I get e-mails from former students telling me how much they love their work and how grateful they are for the preparation they had, it brings me to tears. It is, quite simply, a joy, and when the day is done, I know this is why I am a library educator.

On the other hand, professional education tends, by its very nature, to draw people whose head (and heart) are truly in the application of knowledge. While they may make able practitioners, they do not always make the best students. Now let me say very clearly that there is, in every class, a healthy representation of intellectually engaged students who are motivated by incredible curiosity. But in others, more often than is desirable, there is a subtle anti-intellectualism that is more conducive to training than to learning. Disciplinary theory may seem like so much academic preening, particularly to students who first learned about librarianship as a trade in the work environment. One of my greatest challenges is teaching LIS theory in such a way as to pique the curiosity of those who resist it. Of course, students who come from more academic backgrounds (the person who has completed their master's degree in an academic discipline, but has never 


\section{FROM THE EDITOR}

worked in a library, for example) present unique challenges as well. For some reason, however, training the scholar to be a practitioner is easier than transforming the practitioner into a scholar-librarian. And I would be so bold to say that if educating scholar-librarians is not what we are after, then LIS programs have no business in the university. I also would affirm this mission from the perspective of practice: we need more than those who are trained to perform the functions of a librarian. We need innovative, critical-thinking LIS professionals to confront the challenges of the day.

One particularly troubling manifestation of this natural orientation toward practice is that some students take a very passive role in learning. They want orderly and comfortable training, when real learning is by nature somewhat messy and a little painful. I try to prepare my students for this aspect of graduate education. I tell them that using their minds in new ways is very much like tackling new physical challenges; there is almost always some discomfort involved. We talk about how the ambiguity of new concepts and problems can make them feel insecure at first, and that the only real solution is to engage with material until clarity emerges. I ask them to trust the process. The work of the LIS professional is often carried out in ambiguity (that chemistry question at the reference desk that takes you way out of your element, for example), and I counsel them that comfort with the unknown is essential to excellent practice.

Technology presents a real challenge to this "tell me how to do it and I will" orientation. My main teaching areas are information sources and services and instructional services, both of which are heavily laden with new and quickly developing technologies. I do my best to prepare students to use them. I introduce and demonstrate the basic functions of each new tool. Yet, in reality, the only way to truly learn a new technology is to immerse oneself in it and use it. To do something before they know how to do it is a terrifying prospect for some students. The fact that technology often fails inexplicably to work as it should only confounds learning with frustration. Most of my students come through these technology projects satisfied that, though it was arduous at times, the experience was effective and innately satisfying. Others, such as the one who scrawled "CAPTIVATE BITES MY A**" in capital letters across the length of his or her student evaluation form, remain bitter about the process indefinitely. One of my greatest challenges will continue to be inspiring and empowering these types of students to seize responsibility for their own learning and approach it with confidence and faith.

Peculiar comments aside, my teaching evaluations have been quite strong, and I believe part of what my students value most is my very recent professional experience. I am grateful for this now, but I worry about the future. How will I stay relevant in an applied discipline, particularly one in such flux? I certainly do not have time to work in the field in addi- tion to my current responsibilities. When I daydream about how our courses should be taught, I envision information sources and services based on a clinical model in which the theoretical occupies the classroom and the practical is learned in a real but supervised setting. The advantages to students are obvious, but I would benefit as well. A nursing colleague I know feels clinical supervision is her valuable link to practice. She believes it keeps her up to date and relevant. Unfortunately, resource constraints make this practically impossible (at least at my institution), so it remains a daydream.

On the other hand, I occasionally see my deep roots in the practice of librarianship as a disadvantage to me. Our curriculum is changing - the trend is undeniable. Even my alma mater, which by my estimation has a fairly library-oriented LIS program, has dropped the reference course from its core requirements. We need to prepare students for environments other than libraries-I get that. My information sources and services course is bound to broaden, perhaps eventually becoming information retrieval. Will I know how to teach such a course? Or will I teach it as well? Am I too bound to my identity as a librarian to be an effective LIS professor? In my confident moments, I say yes to the former, and no to the latter. The skills are essentially the same: connecting people to information. But there are some lingering doubts, as well. Will our values and ethics survive?

I suppose the answers to these questions lie to some degree within me. I am only one faculty member, but I am part of this field and have a responsibility to participate in actively shaping our future. I said earlier that I am not trying to tackle the Question of library education, yet here I have made my way back to it somehow. What I do not want to do is become reactive out of fear. In many ways, information science reminds me of the newborn sibling just brought home from the hospital. It is new, exciting, and getting everyone's attention. (Yes, I know information science is older than fifty now, but relatively speaking, it is a young discipline). Meanwhile, the more mature sibling stands by listening to the fuss, feeling threatened, dull, and passé. But in the long run, even the baby will lose its luster. In the end, we will have to get down to the business of raising the child-it will have to grow and mature-and allow it to find its place in society, just as librarianship has done.

For now, a chasm exists between librarianship and information science. Will information science emerge as the esoteric side of the practice of library and information profession? Or will information science emerge as a parallel professional discipline, with its own tension between theory and practice? No matter what the outcome, the tension between the aims of education and the demands of practice will not subside. And educators in the future will walk the same tightrope between them that I myself walk today. 